\title{
Lysurus habungianus sp. nov. (Phallaceae) - A new stinkhorn fungus from India
}

\section{Gogoi $\mathbf{G}^{1}$ and Parkash $V^{2}$}

Rain Forest Research Institute, AT Road, Sotai, Post Box No. 136, Jorhat-785001, Assam, India. E-mail: ${ }^{1}$ gogoigirish30@gmail.com, ${ }^{2}$ bhardwajvpnpark@ rediffmail.com

Gogoi G, Parkash V 2015 - Lysurus habungianus sp. nov. (Phallaceae) - A new stinkhorn fungus from India. Current Research in Environmental \& Applied Mycology 5(3), 248-255, Doi $10.5943 / \mathrm{cream} / 5 / 3 / 7$

\begin{abstract}
This paper presents a description and an illustration of one hitherto undescribed species of stinkhorn under family Phallaceae, genus Lysurus Fr., named as Lysurus habungianus sp. nov. collected from short grassland under Bamboo plantation of Habungia village, Jorhat District, Assam, India.
\end{abstract}

Key words - Dendrogram - macrofungi - Phallaceae - phylogeny - stinkhorn - undescribed

\section{Introduction}

Lysurus Fr. is a genus of fungi belongs to the family Phallaceae commonly known as stinkhorn fungi. The species of Lysurus have a widespread distribution, but are especially prevalent in tropical areas (Kirk et al. 2008). There are records of 30 spp., 7 varieties and 2 forms of Lysurus in the index fungorum (Index Fungorum 2015). In India, Narasimhan (1932), reported Lysurus gardneri Berk. from ground of Mysore, Karnataka. Ahmad (1940), reported Simblum phaerocephalum Schlecht from Rohtak, Punjab and Tewaria \& Khare (1968), reported Simblum periphragmoides Klotzsch from Varanasi, Uttar Pradesh. Later on these two fungi taxonomically shifted to the synonyms of Lysurus periphragmoides. Patil (1978), reported another species of Lysurus named Lysurus sulcatus (Cooke \& Massee) G. Cunn. from well manured garden soil, Kolhapur, Maharashtra. Agarwal et al. (1984), reported Lysurus borealis (Burt) Henn. from Palampur, Himachal Pradesh. Acharya et al. (2010), reported two species of Lysurus namely Lysurus periphragmoides (Klotzsch) Dring (1980) and a Lysurus sp. from Howrah and East Midnapur district of West Bengal. Mohanan (2011) described a new species of Lysurus named Lysurus brahmagiri C. Mohanan from Kerala. Some of the allied species of L. habungianus sp. nov. like L. mokusin (L.) Fr. described as a new record from the Island of Madeira (Portugal) by Calonge \& Goncalves-Silva (2006). This species is also found in Australasia the Canary Islands, Korea, Japan, China and the Bonin Islands. A new distribution of L. cruciatus (Lepr. \& Mont.) Henn. in Bulgaria and southeastern Europe was reported by Assyov \& Gashtarov (2007). Lysurus gardneri (Berk.) new distribution from Czechoslovakia was reported by Kluzak (1974). Recently, Cortez et al. (2011) reported two species of Lysurus namely L. cruciatus and L. periphragmoides (Klotzsch) Dring and one variety of L. cruciatus namely L. cruciatus var. nanus from Rio Grande do Sul State, in southern Brazil. The species is also reported from Africa, Asia, China, Sri Lanka, India, Pakistan, Thailand, Indonesia, Australasia, North America and South America. 
Being a biodiversity hotspot hardly a few species of macrofungi have been newly described from North East India. Gogoi \& Parkash (2014) reported seven species of stinkhorns excluding Lysurus spp. from Hollongapar Gibbon Wildlife Sanctuary, Jorhat, Assam. As per literature review there was no any record of new description as well as distribution of any Lysurus spp. from North East India. There is a great possibility of exploration and descriptions of new species of macrofungi from Assam. In this paper, we are describing a new species of Lysurus species after thorough macro as well as micro morphological studies followed by literature survey.

\section{Materials \& Methods}

Study site (Fig. 1) - The study site is a small village called Habungia under Jorhat district of Assam, India. The village is located at a distance of $8 \mathrm{~km}$ from Jorhat district Head Quarter. There are 68 number of households and almost each household has an own bamboo plantation in the village. The main source of income is found to be cultivation.

Collection and observation - Collection of the specimens were done during June to October 2013 to 2014 from short grassland and Bamboo plantation of Habungia village, Jorhat, Assam (Fig. 1). The specimens were photographed with SONY DSC-H9 camera in their habitat during the survey period. Different identifying characters viz. colour, odour, texture, substratum, size of whole fruit body or its parts, were noted down in the field. Colour codes and terms followed Methuen Handbook of Colour (Kornerup \& Wanscher, 1978). The same specimens were brought to the Laboratory, RFRI, Jorhat for macroscopic and microscopic study and preserved for further study. Micromorphological features were studied from the collected samples mounted in a mixture of $5 \% \mathrm{KOH}, 1 \%$ phloxin, Congo red and 30\% glycerol, and Melzer's reagent. Spore dimensions were measured under Olympus microscope CX41 and photographed the same spores. Twenty numbers of basidiospores were selected in the slide under the microscope to measure dimensions of the spores (Das \& Zhao 2013). The minimum, the maximum and mean value for length and width were measured among the twenty basidiospores. The quotients (length - width ratio) of spore the minimum, the maximum and mean quotient value amongst the measured spores are determined (Das \& Zhao 2013). The specimen was allotted accession number as GG-13-10 (Holmgren et al.1990) and deposited to the Rain Forest Research Institute, Jorhat. Authors' names were abbreviated as per Index Fungorum (2015). Spore measurements are recorded based on those of twenty basidiospores. Spore measurement and quotient indicating length-width ratio $(\mathrm{Q}=\mathrm{L} / \mathrm{W})$ are presented as minimum-mean-maximum. A distribution map was created with the aid of Google Earth (www. google.com/earth). Phylogeny analysis was done by construction of a phylogeny tree or a dendrogram according to UPGMA method (Michener \& Sokal, 1957) using the online dendrogram construction utility, DendroUPGMA (http://genomes.urv.cat/UPGMA) (Garcia-Vallvé et al.1999).

\section{Results}

Ecological study - The fungus is found to be saprobic, where it grows solitarily on short grassland and on mulch of bamboo plantation.

The mature fruit body is originated from white (8A1) to brown (8E6) roughly round, partially buried in the soil or bamboo leaf litter, volva or Egg (Figs 7-8, 12). The volva is attached to the soil with a white (8A1) and thick rhizomorph consists of mass of fungal hyphae. The egg is soft and the peridium is white (8A1) to brown (8E6) colored on the external surface and has gelatinous layer inside (Fig 8). The diameter of a full grown egg was found 2-2.5cm (Figs 7-8, 12). It was observed that an egg took 5-7 days to be full grown and after that it was ruptured as the stipe expanded and broke through in the upper side giving rise the main fruit body of the fungus and the outer layer of the egg was still attached at the base of the matured fruit body, creating a volva at the base of the stipe. The matured fruit body which was 8.5 to $11 \mathrm{~cm}$ high and $2.5-3 \mathrm{~cm}$ width (Figs 5,6 ), differentiated in to a brownish latticed cap, pileus or head (a receptaculum) and a spongy, hollow, white (8A1) to cream coloured (3C) stalk or stipe. The stipe $7-8 \mathrm{~cm}$ high and 2.5 to $3 \mathrm{~cm}$ width, walls composed of 1 layered chamber, wall 0.3 to $0.4 \mathrm{~cm}$. The size of the head was found to be $2.5-3 \mathrm{~cm}$ tall and $3-3.5 \mathrm{~cm}$ width (Fig. 4). The cap formed brown lattice or mesh. There are 52 to 58 small pentagonal to hexagonal meshes on the head. 


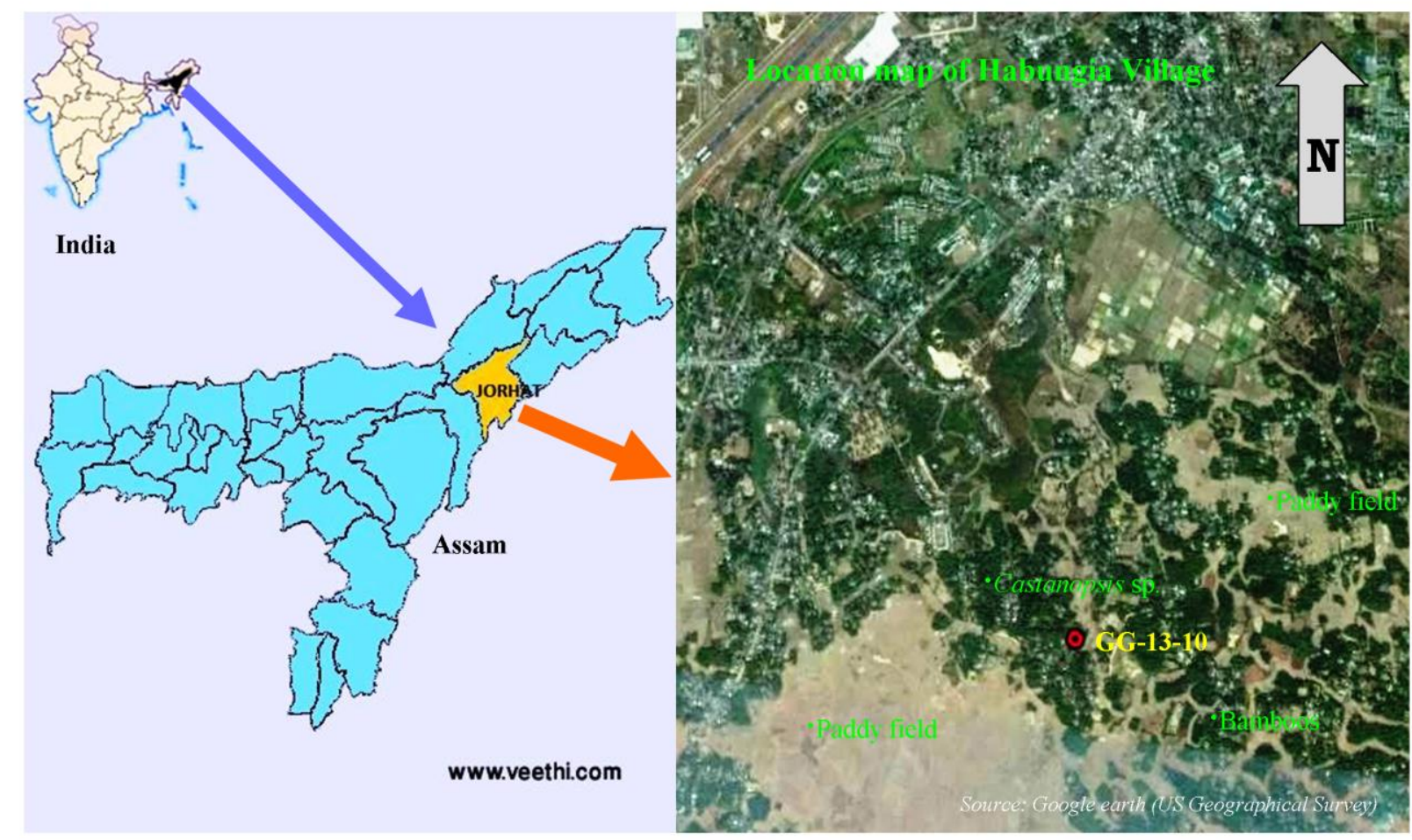

Fig.1 - Map of study site. • (indicates the location of Habungia village on the globe)

The size of the meshes were found to be $3-4 \mathrm{~mm} \times 4-6 \mathrm{~mm}$. Sharp ridges were found on the outer surface of the arms of the mesh, without corrugations on the sides and the inner surface were found to be flat. Some spiny structures were found on the sharp ridges of the outer surface of the arms. The lengths of these spiny structures were found to be $0.5 \mathrm{~cm}$ to $1.5 \mathrm{~cm}$ and white $(8 \mathrm{~A} 1)$ in colour. A dark olive-green spore mass, the gleba, fills the inner surface of the lattice and extended outwards between the arms (Figs 2-6). Like other members of the Phallaceae family, the gleba has a fotid odour that attracts flies and other insects which help to disperse its spores. The stipe has found to be spongy, hollow, cylindrical, white to cream in colour, attained a length $7-8 \mathrm{~cm}$ high and $2.5-3 \mathrm{~cm}$ width (Fig. $6)$.

Microscopic study - Dimension of basidiospores (Figs 9, 11) were measured in side view from 20 numbers of basidiospores. Basiodispores were elongated or elliptical in shape, hyaline thin walled smooth and minutely apiculate. The minimum, maximum and mean value for length of the basidiospores is found to be $4.5 \mu \mathrm{m}, 4.9 \mu \mathrm{m}$ and $4.7 \mu \mathrm{m}$ respectively. Accordingly, the minimum, the maximum and the mean value for width of the basidiospores are found to be $2.4 \mu \mathrm{m}, 2.8 \mu \mathrm{m}$ and 2.6 $\mu \mathrm{m}$ respectively. The minimum, the maximum and the mean quotient value amongst the measured spores were found to be $1.71,1.88$, and 1.81 respectively. Stipe cells were found ellipsoidal to

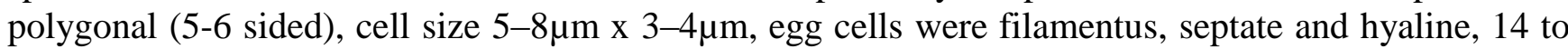
$16 \mu \mathrm{m}$ broad.

Lysurus habungianus G. Gogoi \& V. Parkash, sp. nov.

Figs 2-12

MycoBank No. MB 812277

Facesoffungi number: FoF 00645

TreeBASE Submissions ID: 17469

Etymology - Named after Habungia village, type locality.

Material examined - India, Assam, Jorhat District, Habungia village, short grassland of bamboo plantation, 09 August 2013, G. Gogoi, GG-13-10(Holotype), RFRI-10 (ex-holotype culture), 26.7049 $\mathrm{N}$ Latitude and $94.18648^{\circ} \mathrm{E}$ Longitude, Elevation $102 \mathrm{~m}$. 


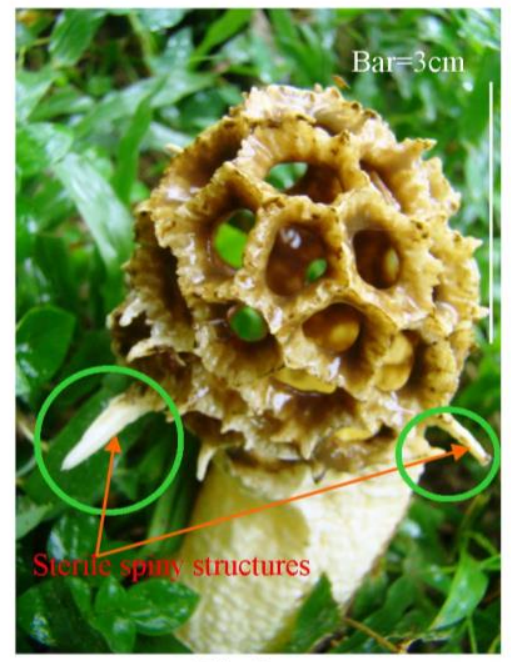

Fig. 2

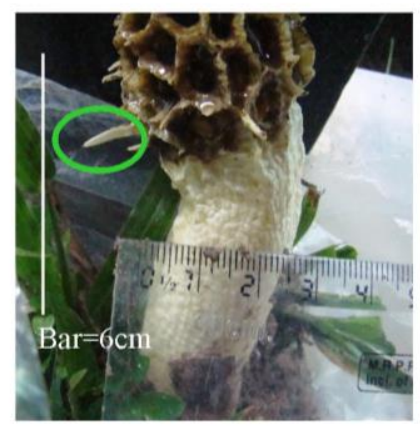

Fig. 5

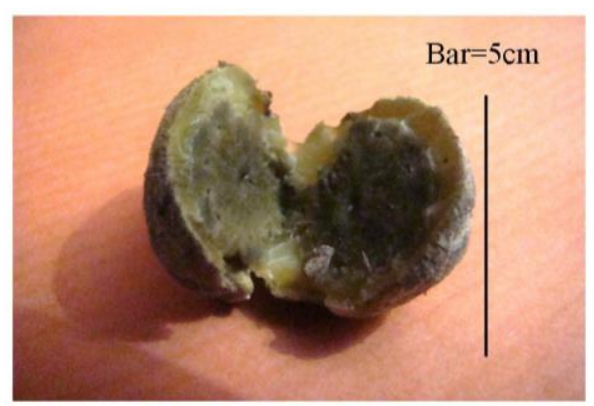

Fig. 8

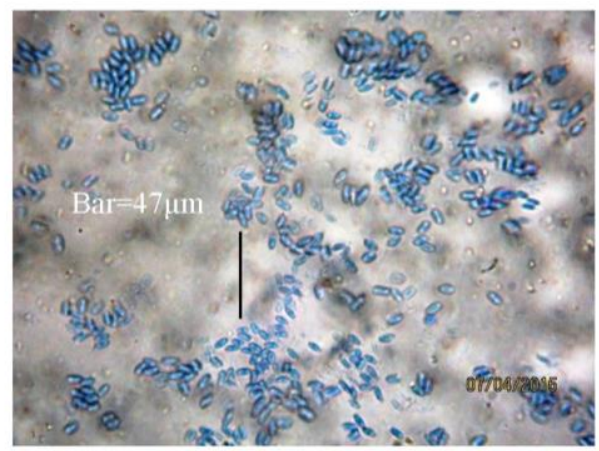

Fig. 9

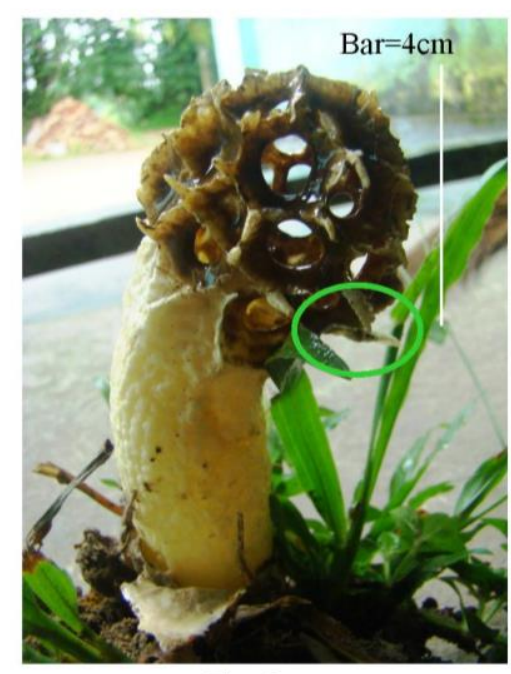

Fig. 3

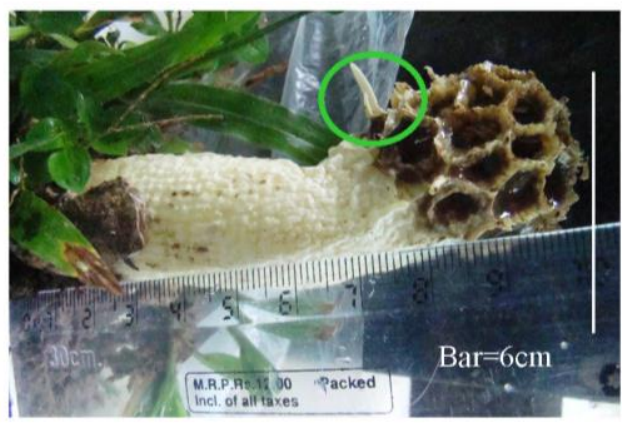

Fig. 6

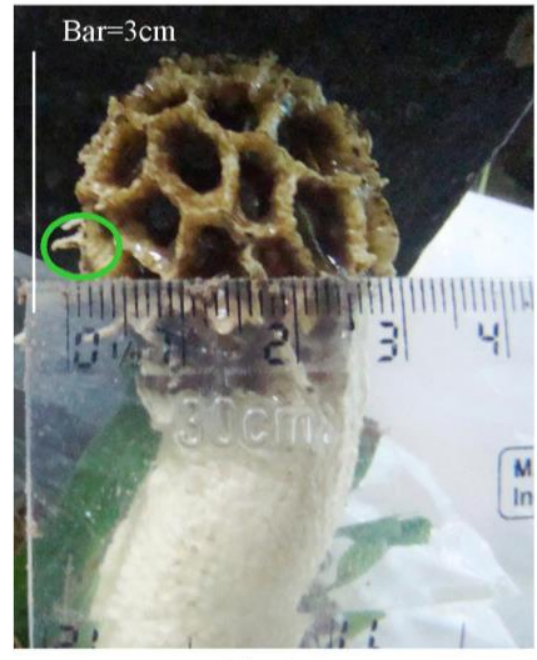

Fig. 4

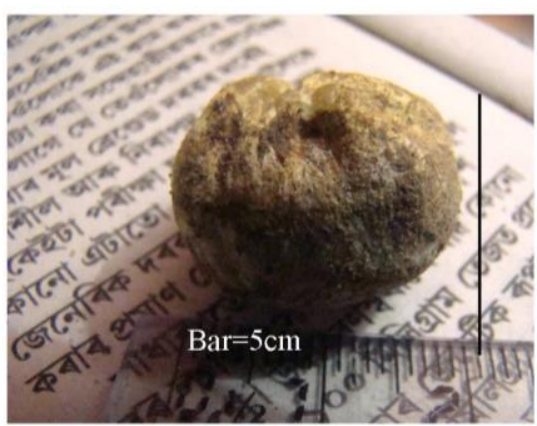

Fig. 7

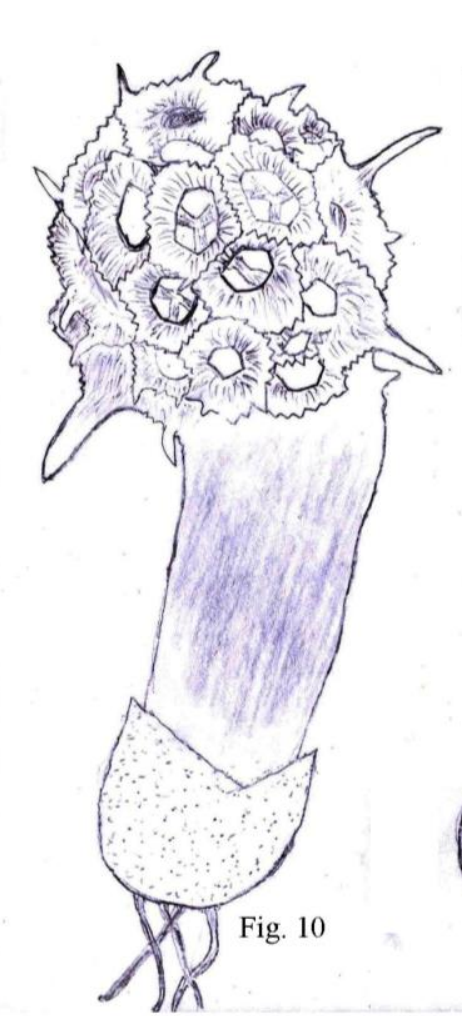

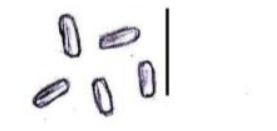

Fig. $11 \quad$ Bar $=12 \mu \mathrm{m}$

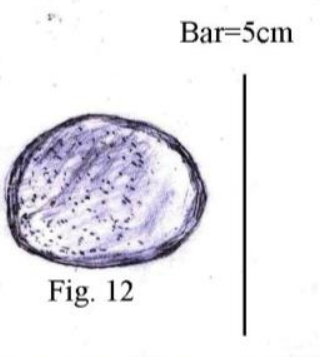

Figs 2-6 - Fruit bodies of Lysurus habungianus sp. nov. Figs 7-8 - Eggs, Fig. 9 - Basidiospores,

Fig. 10 - Line diagram of Lysurus habungianus sp. nov. Fruit body, Fig. 11 - Line diagram of Basidiospores, Fig. 12 - Line diagram of an Egg 


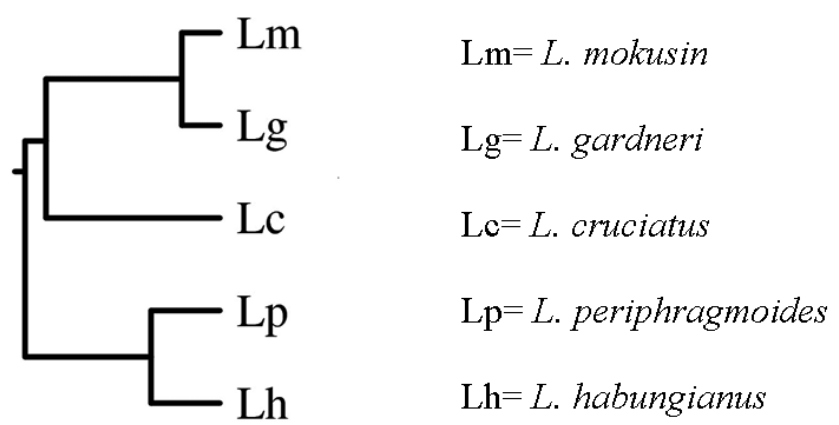

Fig.13 - A classical Phylogenetic tree or dendrogram of five Lysurus spp. using the online dendrogram construction utility, DendroUPGMA

Table 1 Morphological comparison of Lysurus habungianus sp. nov. with four allied species.

\begin{tabular}{|c|c|c|c|c|c|}
\hline Sl. No & 1 & 2 & 3 & 4 & 5 \\
\hline \multirow{2}{*}{$\begin{array}{l}\text { Lysurus spp. } \\
\text { Fruit body } \\
\text { size }\end{array}$} & $\begin{array}{l}\text { L. mokusin (L.) Fr., Syst. } \\
\text { mycol. (Lundae) 2(2): } \\
288 \text { (1823) }\end{array}$ & $\begin{array}{l}\text { L. cruciatus (Lepr. \& } \\
\text { Mont.) Henn., Hedwigia } \\
\text { 41(Beibl.): (172) }(1902)\end{array}$ & $\begin{array}{l}\text { L. gardneri } \text { Berk., } \\
\text { London J. Bot. 5: } 535 \\
(1846)\end{array}$ & $\begin{array}{l}\text { L. periphragmoides } \\
\text { (Klotzsch) Dring, Kew } \\
\text { Bull. 35(1): } 70(1980)\end{array}$ & L. habungianus sp. nov. \\
\hline & $11-18 \mathrm{~cm} \times 1.5-3 \mathrm{~cm}$ & $6-15 \times 1-2 \mathrm{~cm}$ & $17 \mathrm{~cm} \times 2 \mathrm{~cm}$ & 7- $15 \mathrm{~cm} \times 3.5$ & $8.5-11 \mathrm{~cm} \times 3-3.5 \mathrm{~cm}$ \\
\hline Egg Size & $1-3 \mathrm{~cm}$ & $5 \mathrm{~cm}$ & $3 \mathrm{~cm}$ & $5 \mathrm{~cm}$ & $2.5 \mathrm{~cm}$ \\
\hline Egg colour & White & White & White & white or buff & White or brown \\
\hline Stipe shape & Angular(4-6 arms fused) & Cylindrical, hollow, single & $\begin{array}{l}\text { Cylindrical, hollow, } \\
\text { single }\end{array}$ & $\begin{array}{l}\text { Cylindrical, hollow, } \\
\text { single }\end{array}$ & $\begin{array}{l}\text { Cylindrical, hollow, } \\
\text { single }\end{array}$ \\
\hline Stipe colour & White to pink to red & White or yellow & White & Orange to reddish & White or cream \\
\hline Stipe size & $10-15 \mathrm{~cm} \times 1.5-2.5 \mathrm{~cm}$ & $5-12.5 \mathrm{~cm} \times 1-2.5$ & $15 \mathrm{~cm} \times 2 \mathrm{~cm}$ & $6-11.5 \mathrm{~cm} \times 1-3 \mathrm{~cm}$ & $7-8 \mathrm{~cm} \times 2.5-3 \mathrm{~cm}$ \\
\hline Cap shape & Angular (4-6 arms fused) & 4-7 arms (free) & 4-6 arms united at tip & Latticed spherical & Latticed spherical \\
\hline $\begin{array}{l}\text { Cap size } \\
\text { Spore shape }\end{array}$ & $\begin{array}{l}0.8 \text { to } 3 \mathrm{~cm} \text { long } \\
\text { Cylindical, smooth, } \\
\text { hyaline }\end{array}$ & $\begin{array}{l}1-2.5 \mathrm{~cm} \text { long } \\
\text { Elliptical to oblong, } \\
\text { smooth }\end{array}$ & $\begin{array}{l}1.5-2 \mathrm{~cm} \text { long } \\
\text { Elliptical, smooth. } \\
\text { hyaline }\end{array}$ & $\begin{array}{l}1.5-3.5 \mathrm{~cm} \\
\text { Elliptical to oblong, } \\
\text { smooth. }\end{array}$ & $\begin{array}{l}3-3.5 \mathrm{~cm} \\
\text { Elliptical to oblong, } \\
\text { smooth }\end{array}$ \\
\hline Spore size & $4-6 \times 2-2.5 \mu \mathrm{m}$ & $3-4 \times 1.5-2 \mu \mathrm{m}$ & $4-5 \times 1.5 \mu \mathrm{m}$ & $3.5-4.5 \times 1.5-2 \mu \mathrm{m}$ & $4.7 \times 2.6 \mu \mathrm{m}$ \\
\hline
\end{tabular}


Notes - The matured fruit body which was found 8.5 to $11 \mathrm{~cm}$ high and $2.5-3 \mathrm{~cm}$ width. The stipe was found spongy, hollow, white (8A1) to cream colored (3C) with $7-8 \mathrm{~cm}$ high and 2.5 to $3 \mathrm{~cm}$ width. The cap formed brown (8E6) lattice or mesh. There were 52 to 58 small pentagonal to hexagonal or irregular meshes on the head. The size of the meshes was found to be $3-4 \mathrm{~mm} \times 4-6 \mathrm{~mm}$. Sharp ridges were found on the outer surface of the arms of the mesh, without corrugations on the sides and the inner surfaces were found to be flat. Some sterile, white (8A1) and spiny structures were seen on the sharp ridges of the outer surface of the arms originating from the adjoining area of arms of the mesh (Figs 2-6). The length of these spiny structures was found to be 0.5 to $1.5 \mathrm{~cm}$. The minimum, the maximum and the mean value for length of the basidiospores were found to be $4.5 \mu \mathrm{m}, 4.9 \mu \mathrm{m}$ and 4.7 $\mu \mathrm{m}$ respectively. Accordingly, the minimum, the maximum and the mean value for width of the basidiospores were found to be $2.4 \mu \mathrm{m}, 2.8 \mu \mathrm{m}$ and $2.6 \mu \mathrm{m}$ respectively. The minimum, the maximum and the mean quotient value amongst the measured spores were found to be 1.71, 1.88, and 1.81 respectively.

\section{Phylogeny analysis}

Morphological features of four allied species of Lysurus habungianus sp. nov. were collected from the existing literatures and tabulated (Table 1) as follows for phylogeny analysis by using UPGMA (Unweighted pair group method with arithmetic mean). A phylogenetic tree or dendrogram (Fig.13) was constructed from the tabulated morphological features of the five Lysurus spp.

Phylogenetic tree (Fig.13) showed that all the five fungal species were originated from same ancestral gene; Lysurus habungianus and L. periphragmoides belong to the same clade which was parallel to each other in their evolutionary line and both were more primitive than the rest three species. Lysurus cruciatus formed an independent branch which was slightly advanced in comparison to the previous two species. L. gardneri and L. mokusin formed a separate branch parallel to $L$. cruciatus. $L$. mokusin was found most advance species in comparison to the other four species. $L$. gardneri and $L$. mokusin were belonging to the same clade but parallel to each other in their evolutionary line.

\section{Discussion}

Lysurus habungianus sp. nov. is morphologically distinct, and unlikely to be confused with any other species, like Lysurus mokusin (L.) Fr. which has a distinct angular form of stipe (Tejera et al. 1998) and this character differentiated the species from other Lysurus spp. L. mokusin is the type species of the genus Lysurus (Lysurus Fr. Mycobank retrieved 2015). The "eggs" of L. mokusin are white, gelatinous measuring 1-3 cm in diameter, and are attached to the ground by thickened strands of mycellium called rhizomorphs. The stipe of the hollow, spongy mature fruiting body has dimensions of $10-15 \mathrm{~cm}$ by $1.5-2.5 \mathrm{~cm}$ and ranges in color from white to pink to red, with 4-6 distinct deeply grooved sides divided lengthwise by ribs. The spores are cylindrical in shape, smooth, thin-walled, and hyaline, with dimensions of $4-6$ by $2-2.5 \mu$ m (Smith 2005).

Lysurus cruciatus (Lepr. \& Mont.) Henn. initiate from an white colour "egg" up to $5 \mathrm{~cm}$ across and matured fruit body is $6-15 \mathrm{~cm}$ high, consisting of a stem with a head composed of 4-7 (but usually 5) arms. The arms are 1-2.5 cm long, short and thick, hollow, and three-sided. The stem is $1-2 \mathrm{~cm}$ thick, and is usually tapered downward. It is hollow and white, or tinged yellowish above and white below. Basidiospores are Spores 3-4 x 1-2 $\mu \mathrm{m}$; elliptical to oblong and smooth (Miller \& Miller 2006). In Lysurus gardneri Berk. the "egg" is whitish up to $3 \mathrm{~cm}$ across and the stipe is more or less cylindrical, hollow, up to $15 \mathrm{~cm}$ long and $2 \mathrm{~cm}$ thick, white, lumpy and wrinkled. Head composed of 46 short arms that are usually united at their tips. Arms white, lumpy, each with a sterile basal portion that is not covered with spore slime, on the upper, inner surfaces finely velvety, markedly lumpy, and covered with dark brown spore slime (Kuo 2013). Basidiospores have dimension of 4-5 x $1.5 \mu \mathrm{m}$.

Lysurus periphragoides (Klotzsch) Dring which is commonly called as the stalked lattice stinkhorn or chambered stinkhorn (McKnight \& McKnight 1987) and it was originally described as Simblum periphragmoides in 1831. The basidiomata of this species, extend up to $15 \mathrm{~cm}$ tall, consists of a reddish latticed head (a receptaculum) placed on top of a long, hollow, cylindrical, reddish stalk. The white to buff colored "egg" grows up to $5 \mathrm{~cm}$ in diameter and the matured basidiomata are up to $15 \mathrm{~cm}$ 
tall. The cap or receptaculum is typically $1.5-3.5 \mathrm{~cm}$ in diameter and forms a red or orange lattice, or mesh. The stipe is $5-15 \mathrm{~cm}$ by $0.8-3 \mathrm{~cm}$ thick. Basidiospores are elliptical or oblong in shape, smooth and have dimensions of $3.5-4.5$ by $1.5-2.5 \mu \mathrm{m}$.

The species Lysurus habungianus is similar to Lysurus periphragoides (Klotzsch) Dring which is commonly called as stalked lattice stinkhorn or chambered stinkhorn. Although, L. periphragoides is a morphologically variable species, as a result, it has acquired an 18 number of synonyms (Kirk et al. 2008). Still, the present species can be differentiated on the basis of white, sterile, spiny structures found on the upper side of the chambered head of the species which were not ever been observed and reported earlier. Moreover, in L. periphragoides the stipe and head are generally yellow or red in colour (Guzman 1984) but in L. habungianus the stipe is always cream or white and the cap is always brown in colour. The classical phylogenetic tree (Fig. 13) also showed that the L. habungianus is the most primitive in comparison to the other four allied fungal species and it has very much similarity with $L$. periphragmoides but both were parallel to each other in their evolutionary line.

\section{Acknowledgements}

Authors would like to thank, Director, RFRI, Jorhat; Dr. Kanad Das, Deputy Director, BSI, Kolkata; Prof. Iuri Goulart Baseia from Brazil; Dr. B.M. Sharma, Senior Professor, Palampur; Prof. Dr. Krishnendu Acharya, Senior Professor, Kolkata; Prof. M. Krishnappa, Karnataka for providing valuable suggestions and continuous inspirations to carry out our study; Mrs. Rajkumari Uzzalla Singha for line drawing of the fungus and Mr. Ankur Jyoti Saikia for assisting in laboratory works.

\section{References}

Acharya K, Pradhan P, Chakraborty N, Dutta AK, Saha S, Sarkar S, Giri S. 2010 -Two new species of Lysurus Fr.- addition to the Macrofungi of West Bengal. J. Botan. Soc. Bengal 64 (2), 175-178.

Agarwala RK, Gupta KK, Kumar S, Seth PK.1984 - Gasteromycetes of Himachal Pradesh, Indian Phytopath. 27, 45-48.

Ahmad S. 1940 - Higher fungi of the Punjan Plains-II. The Gasteromycetes. J. Ind. Bot. Soc. 18, 169177.

Assyov B, Gashtarov V. 2007 - Lysurus cruciatus (Phallales) - first record in Bulgaria and southeastern Europe - Mycologia Balcanica 4, 93- 94.

Calonge FD, Goncalves-Silva JJ. 2006 - Lysurus mokusin, Phallales. Basidiomycota, a new species for the Island of Madeira (Portugal). Bol. Soc. Micol. Madrid, 30, 95-97.

Cortez VG, Baseia IG, da Silveira RMB. 2011 - Gasteroid mycobiota of Rio Grande do Sul State, Brazil: Lysuraceae (Basidiomycota) 33(1), 87-92, Doi: 10.4025/actascibiolsci.v33i1.6726

Das K, Zhao RL. 2013 - Nidula shingbaensis sp. nov., a new bird's nest fungus from India. Mycotaxon $125,53-58$.

Dring DM. 1980 - Contributions towards a rational arrangement of the Clathraceae. Kew Bulletin 35

(1), 1-96, Doi:10.2307/4117008.

Garcia-Vallvé S, Palau J, Romeu A. 1999-Horizontal gene transfer in glycosyl hydrolases inferred from codon usage in Escherichia coli and Bacillus subtilis. Mol. Biol. Evol. 16(9), 1125-1134.

Gogoi G, Parkash V. 2014 - Some New Records of Stinkhorns (Phallaceae) from Hollongapar Gibbon Wildlife Sanctuary, Assam, India, Doi: http://dx.doi.org/10.1155/2014/490847

Guzman G. 1984 - New records of Lysurus periphragmoides from Mexico. Boletin de la Sociedad Mexicana de Micologia 19, 169-172.

Holmgren PK, Holmgren NH, Barnett LC. 1990 - Index Herbariorum. Part 1: Herbaria of the world, 8th ed. Regnum Vegetabile.

Index fungorum 2015 - www.indexfungorum.org/Names/AuthorsOfFungalNames.asp. accessed on 07.08.2015.

Kluzak Z. 1974- Lysurus gardneri new record for czechoslovakia. Ceska Mykologie 28(3), 181- 184.

Kirk PM, Cannon PF, Minter DW, Stalpers JA. 2008 - Dictionary of the Fungi. 10th ed. Wallingford, UK: CABI. 395pp. 
Kornerup A, Wanscher JH. 1978 - Methuen Handbook of Colour. Third Edition. UK, London, Eyre Methuen Ltd. Reprint.

Kuo M. 2013 - Lysurus gardneri. Retrieved from the MushroomExpert.Com Web site: http://www.mushroomexpert.com/lysurus_gardneri.html

Lysurus Fr. 2015 - Mycobank, International Mycological Association, Retrieved 2015-08-05.

McKnight VB, McKnight KH. 1987 -A Field Guide to Mushrooms, North America, Boston, Massachusetts: Houghton Mifflin. 346pp.

Michener C, Sokal R. 1957 - A quantitative approach to a problem in classification. Evolution 11, $130-162$.

Miller Jr. OK, Miller HH.2006 - North American Mushrooms: A Field Guide to Edible and Inedible Fungi. Falconpress, Guilford, Conn.

Mohanan C. 2011 - KFRI Handbook (Peechi) 27, 364pp.

Narasimhan MJ. 1932 -The Phalloideae of Mysore. J. Ind. Bot. Soc. 11, 253pp.

Patil MS.1978 -Some fleshy fungi from Maharashtra-III. Indian Phytopath. 31, 32-35.

Smith KN. 2005 - A Field Guide to the Fungi of Australia. Sydney, NSW, Australia: University of New South Wales Press. 198pp.

Tejera EB, Baudet AB, Rodriguez-Armas JL. 1998 - Gasteromycetes on the Canary Islands: Some noteworthy new records. Mycotaxon 67, 439-453.

Tewaria VP, Khare KB. 1968 - Two interesting Phalloids from Uttar Pradesh. Indian Phytopath.21, 374-378. 